\title{
ПРОГНОЗУВАННЯ ПЕРЕБІГУ ТА РЕЗУЛЬТАТУ ЛІКУВАННЯ ІНВАГІНАЦІЇ КИШЕЧНИКА У ДІТЕЙ
}

\author{
С. В. Веселий, М. Ю. Веселий \\ Донецький національний медичний університет імені М. Горького
}

\begin{abstract}
Вивчений катамнез у 150 дітей з інвагінацією кишечника в строки від 6 місяців до 15 років після операції. Комплексне біохімічне та імунологічне обстеження проведене 30 пацієнтам. Крім того, проведене морфологічне дослідження 10 біоптатів парієтапьної очеревини, узятих під час оперативного лікування. Вивчення передопераційного, інтраопераційного та післяопераційного стану хворих, а також прогнозування перебігу та результату захворювання проводили в результаті пошуку «факторів ризику», що визначають імовірність виникнення та тяжкості клінічного перебігу інвагінації кишечника у дітей. У ранньому післяопераційному періоді померли 4 дитини (2,7 \%) у зв'язку з неспроможністю анастомозу, множинними кишковими норицями та прогресуванням перитоніту. Катамнестичне спостереження виявило, що 104 дитини (69,3 \%) після оперативної дезінвагінації росли та розвивалися відповідно до віку. У 34 пацієнтів $(22,7$ \%) надалі виникла гастроентеропатія, що характеризувалася періодичними дисфагічними та диспепсичними явищами. У 12 дітей $(8,0 \%)$ розвинулася спайкова хвороба. Термін спостереження та проведення реабілітаційних заходів у дітей після оперативної дезінвагінації повинен визначатися за обліком ступеня ризику виникнення пізніх ускладнень.
\end{abstract}

Ключові слова: інвагінація кишечника, фактори ризику, біохімічні, імунологічні, морфологічні показники.

\section{ПРОГНОЗИРОВАНИЕ ТЕЧЕНИЯ И ИСХОДА ЛЕЧЕНИЯ ИНВАГИНАЦИИ КИШЕЧНИКА У ДЕТЕЙ}

\author{
С. В. Весёлый, Н. Ю. Весёлый \\ Донецкий национальный медицинский университет имени М. Горького
}

\begin{abstract}
Изучен катамнез у 150 детей с инвагинацией кишечника в сроки от 6 месяцев до 15 лет после операции. Комплексное биохимическое и иммунологическое обследование проведено 30 пациентам. Кроме того, проведено морфологическое исследование 10 биоптатов париетальной брюшины, взятых во время оперативного лечения. Изучение предоперационного, интраоперационного и послеоперационного состояния больных, а также прогнозирование течения и исхода заболевания проводили в результате поиска «факторов риска», определяющих вероятность возникновения и тяжесть клинического течения инвагинации кишечника у детей. В раннем послеоперационном периоде умерло 4 детей $(2,7 \%)$ в связи с несостоятельностью анастомоза, множественными кишечными свищами и прогрессированием перитонита. Катамнестическое наблюдение выявило, что 104 ребенка (69,3\%) после оперативной дезинвагинации росли и развивались соответственно возрасту. У 34 пациентов (22,7\%) в дальнейшем диагностирована гастроэнтеропатия, характеризующаяся периодическими дисфагическими и диспепсическими явлениями. У 12 детей (8,0 \%) развилась спаечная болезнь. Сроки наблюдения и проведения реабилитационных мероприятий у детей после оперативной дезинвагинации должны определяться с учетом степени риска возникновения поздних осложнений.
\end{abstract}

Ключевые слова: инвагинация кишечника, факторы риска, биохимические, иммунологические, морфологические показатели.

\section{PREDICTING THE COURSE AND OUTCOME OF THE TREATMENT OF INTUSSUSCEPTION IN CHILDREN}

\author{
S. V. Veselyi, M. Yu. Veselyi \\ Donetsk National Medical University by M. Horkyi
}

\begin{abstract}
The catamnesis in 150 children with an intussusception in terms from 6 months till 10 years after surgical intervention is investigated. Complex biochemical and immunological inspection is carried out to 30 patients. Besides morphological research 10 bioptats of the taken parietal peritoneum, is carried out during operative treatment. Studying before-, intraand postoperative condition of patients, and also forecasting of current and outcome of disease carried out as a result of search of the «risk factors» determining probability of occurrence and gravity of clinical current of the invagination of
\end{abstract}


intestine in children. In the early postoperative period 4 children $(2.7 \%)$ have died in connection with an incompetence of the anastomosis, plural intestinal fistulas and progressing of the peritonitis. Catamnesis observation has revealed, that $104(69.3 \%)$ the child after operative desinvagination grew and developed according to age. 34 patients $(22.7 \%)$ further had the gastroenteropathy described periodic dysphagia and dyspepsia by the phenomena. In 12 children (8.0\%) the adhesive disease has developed. Patients with high risk of occurrence of late complications after operative desinvagination require long-term observation and rehabilitation actions.

Key words: intussusceptions, risk factors, biochemical, immunological, morphological parameters.

Вступ. Найчастішою формою непрохідності кишечника у дітей є інвагінація. В осіб чоловічої статі це захворювання зустрічається в 1,5-2 рази частіше, ніж жіночої $[2,3,6]$. Найчастіше зустрічається клубово-ободова інвагінація (45-60\%), сліпо-ободова (20-25\%),товстокишкова(12-16\%),тонкокишкова (10-16 \%). У переважній більшості спостережень (до $80 \%$ випадків) інвагінація виникає у віці 3-11 місяців, проте останнім часом відзначається значне збільшення кількості хворих з інвагінацією кишечника у віці старше 1 року $[2,7,9]$. До теперішнього часу існують проблеми, які стосуються етіопатогенезу, оптимізації діагностики і методів лікування, а також реабілітації пацієнтів $з$ кишковою інвагінацією [10]. Особливого прогресу в лікуванні гострої форми інвагінації кишечника у дітей за останні 20 років не відбулося, про що свідчать стабільні цифри ускладнень і летальності, яка, за даними різних авторів, становить від 2,7\% до 5,4 \% [4, 5, 8]. У близько 7,5 \% дітей, які перенесли оперативну дезінвагінацію, виконують повторні оперативні втручання у зв'язку з розвитком ранніх і пізніх післяопераційних ускладнень, основним з яких є розвиток спайкової кишкової непрохідності [2, 9]. У лікувальних установах, які використовують малоінвазивні відеохірургічні методи лікування інвагінації кишечника у дітей, спостерігають поодинокі випадки післяопераційної спайкової хвороби [3].

Мета дослідження: розроблення якісних i кількісних критеріїв оцінювання тяжкості перебігу інвагінації кишечника у дітей.

Матеріали та методи досліджень. Досліджений катамнез у 150 дітей з інвагінацією кишечника в терміни від 6 місяців до 20 років після операції. Пацієнтів, яким була успішно проведена консервативна дезінвагінація, до даного дослідження не включили. Осіб чоловічої статі було 91 (60,7 \%), жіночої - 59 (39,3%). У віці до 3 місяців було госпіталізовано 4 дітей (2,7 \%), 3,1-6 місяців - 48 (32,0\%), 6, 1 12 місяців-62 (41,3\%), 12,1-18 місяців-11 (7,3\%), 18,1 міс.-І3 років-25 дітей(16,7 \%). Таким чином, переважна більшість пацієнтів захворіли у віці 3,1-12 місяців (73,3 \%). Тривалість клінічних проявів захворювання до моменту надходження в стаціонар становила у 63 хворих (42,0\%) до 12 годин, у 44 (29,3 \%)-12,1 -24 години, у 31 (20,7 \%)-24, 1 -48 годин, і у 12 (8,0 \%) - понад 48,1 години. Тонко-товстокишкова інвагінація спостерігалася у 127 дітей (84,7 \%), тонкокишкова-у 20 дітей (13,3%), по 1 випадку $(0,7$ \%) припало на сліпо-ободову інвагінацію, товстокишкову інвагінацію та інвагінацію червоподібного відростка. Всім пацієнтам були проведені лапаротомія, дезінвагінація. Додатковий обсяг оперативної допомоги визначався характером патологічних змін та станом ураженої ділянки кишечника.

Комплексне біохімічне та імунологічне обстеження проведено у 30 пацієнтів. Виконано морфологічне дослідження 10 біоптатів парієтальної очеревини, які були взяті під час оперативного лікування. Вивчення передопераційного, інтраопераційного та післяопераційного стану хворих, а також прогнозування перебігу та результату захворювання проводили в результаті пошуку "факторів ризику", які визначають ймовірність виникнення та тяжкість клінічного перебігу інвагінації кишечника у дітей. Вказану проблему вирішували експертним шляхом, оптимізацію рішення підтвердили методом кількісної оцінки значимості відхилень клінічних ознак від норми [4]. Для цього аналізували 210 ознак інвагінації кишечника, які включають дані анамнезу, клінічного обстеження, лабораторних, спеціальних та інструментальних методів. В силу застосування дискретних і безперервних шкал вимірювання при реєстрації клінічної інформації, статистична обробка проводилася зі застосуванням критеріїв параметричної та непараметричної статистики.

Результати та їх обговорення. Після аналізу виявлених факторів ризику з'ясувалося, що високу експертну оцінку, крім загальновизнаних градацій (вид кишкової інвагінації, давність захворювання, об'єм оперативного втручання тощо), мають лише деякі 3 них.

У процесі вивчення результатів біохімічного дослідження особливу увагу звертали на динаміку активності процесів перекисного окиснення ліпідів й антиоксидантної системи, а також деяких інших 
індукторів стресу. Ці показники чітко відображають закономірності розвитку нозологічної конфігурації і стан резервних механізмів адаптації (табл. 1). У всіх дітей були виражені ознаки ендотоксикозу, однак апріорно передбачалися значні коливання біохімічних показників на користь хворих, що перенесли резекцію кишечника. Насправді коливання виявилися невеликі, в межах 1,8-7,4\%. Це не відноситься до пацієнтів 3 давністю захворювання більш ніж 24 години, які надійшли до клініки з явищами шоку - токсичні продукти у них наростали лавиноподібно. В цілому, для інвагінації кишечника характерні спочатку висока активність катепсину Д, кінцевих продуктів перекисного окиснення ліпідів, а також зниження концентрації неорганічного фосфору й а-токоферолу. Майже удвічі, порівняно 3 нормою, збільшувалося накопичення молекул середньої молекулярної маси і, відповідно, значення коефіцієнта ароматичності та пептидно-нуклеотидного коефіці- єнта. У разі сприятливого перебігу післяопераційного періоду всі ці показники поверталися до нормальних цифр впродовж трьох діб. На відміну від них, у хворих з неспроможністю анастомозу та повною ранньою спайковою непрохідністю кишечника в перші три доби після операції відзначалося лавиноподібне наростання активності катепсину Д більш ніж в 4 рази, сіалових кислот - більш ніж в 3 рази; молекул середньої молекулярної маси та індексів співвідношення, а також продуктів перекисного окиснення ліпідів. Починаючи 7 доби несприятливого перебігу захворювання концентрація сіалових кислот і активність катепсину Д наростали незначно або навіть мали тенденцію до зниження. У чотирьох хворих, які померли, крім перерахованих факторів прогресивно знижувалися показники антиоксидантної системи, активність креатинфосфокінази та рівень неорганічного фосфору.

Таблиця 1. Біохімічні критерії несприятливого перебігу інвагінації кишечника у дітей

\begin{tabular}{|c|c|}
\hline Біохімічні показники & M $\pm \mathbf{m}$ \\
\hline Дієнові кон'югати (умовні одиниці) & $2,50 \pm 0,23$ \\
\hline Малоновий діальдегід (мкмоль/гхбілка) & $7,49 \pm 0,75$ \\
\hline Супероксиддисмутаза (Е/мгхбілка) & $0,104 \pm 0,023$ \\
\hline Каталаза (мкатал/л) & $18,9 \pm 0,8$ \\
\hline Фосфор неорганічний (ммоль/л) & $0,82 \pm 0,07$ \\
\hline Сіалові кислоти (ммоль/л) & $1,82 \pm 0,26$ \\
\hline Катепсин-D (умовні одиниці/млххв) & $4,29 \pm 0,71$ \\
\hline Середні молекули (ум. од. оптичної щільності) & $0,33 \pm 0,03$ \\
\hline Коефіціснт ароматичності & $9,60 \pm 2,38$ \\
\hline а-токоферол (мкмоль/л) & $4,58 \pm 0,48$ \\
\hline
\end{tabular}

Аналіз результатів імунологічного дослідження показує, що стресова реакція організму при сприятливому післяопераційному перебігу кишкової інвагінації не супроводжується вираженим пригніченням імунологічної реактивності навіть при некрозі кишечника. У хворих з неспроможністю кишкового анастомозу, повною ранньою спайковою непрохідністю та прогресуючим перитонітом критичний стан супроводжувався вираженим пригніченням прогностичних маркерів. Зазначалося зниження рівня Влімфоцитів і Т-лімфоцитів, зниження співвідношення супресорів і хелперів, фагоцитарного показника Talg А. Збільшувалася кількість циркулюючих імунних комплексів, наростав титр парієтальних мезотеліальних антитіл (табл. 2).

Таблиця 2. Імунологічні критерії несприятливого перебігу інвагінації кишечника у дітей

\begin{tabular}{|c|c|c|}
\hline Ga ZnHhAi Znuml P(Zul иo & СириятНивийиеребно & НесириятНивийоеребғо \\
\hline $12340-$ - & расосрарнів $2 г$ & раоссрарлів у2г \\
\hline ь фв2їзтіг & раблс рарбгв у $2 \Gamma$ & раохс рармгв у $2 \Gamma$ \\
\hline $\mathrm{b}_{\mathrm{s}} \mathrm{yb}_{H} \mathrm{~T}$ & оуоахлг & оуожг \\
\hline и, ГжТ & саос рапाв у $2 \Gamma$ & оасрраству2г \\
\hline шн пзечт0 ЕНВі д-Р[г & нхалс бан5 $\Gamma$ & оба 9 с налі5 r \\
\hline ] і те[26 6 Дз34 [яя яе-4ї 2зечі г & ххжснеап4 еГУА 2г & ноєамслоап4 еГУА 2г \\
\hline 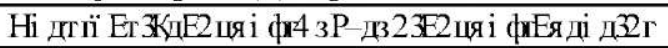 & раронсраррег & раррксраррнт \\
\hline
\end{tabular}


3 морфологічних показників найбільшу прогностичну вагу мали кількісні поляризаційно-оптичні характеристики колагенових волокон очеревини. У дітей з ускладненим перебігом кишкової інвагінації відзначено зниження як якісних, так і кількісних показників анізотропії колагенових волокон, таких як ступінь подвійного променезаломлення та дихроїзм, аж до повного їх зникнення на окремих ділянках очеревини. У пацієнтів 3 давністю захворювання 48 годин і більше найвираженішою була запальна реакція у вигляді дифузної інфільтрації очеревини нейтрофільними поліморфноядерними лейкоцитами. Це призводило до осередкового повного лізису колагенових волокон, який обумовлений викидом гідролітичних ферментів, що продукуються цими лейкоцитами. Прогностично несприятливими були зниження індексу поляризації і фенольного індексу, а також різке зростання значень глікозаміногліканів і нейтральних мукополісахаридів, які є маркерами дестабілізації колагенових фібрил. Це свідчило про розвиток у колагенових волокнах очеревини у дітей виражених вторинних змін, які проявлялися не тільки мукоідним і фібриноідним набуханням, а й фібриноідним некрозом.
Характер ранніх післяопераційних ускладнень у хворих, що спостерігалися, представлений в таблиці 3. У ранньому післяопераційному періоді померло 4 дітей $(2,7 \%)$ у зв'язку з неспроможністю анастомозу, множинними кишковими норицями $\mathrm{i}$ прогресуванням перитоніту. Катамнестичне спостереження виявило, що 104 дитини (69,3\%) після оперативної дезінвагінації росли і розвивалися відповідно до віку. Вони більше не надходили в хірургічний стаціонар; анкетування та опитування не виявили скарг, що характеризують ентеритичний дискомфорт. У 34 пацієнтів (22,7 \%) надалі діагностовано гастроентеропатію, яка характеризувалася періодичними дисфагічними та диспепсичними явищами. Ці діти перебувають на диспансерному спостереженні у гастроентеролога. У 12 дітей $(8,0 \%)$ розвинулася спайкова хвороба, що проявляється епізодами часткової спайкової кишкової непрохідності. Троє 3 них перенесли релапаротомію $з$ приводу повної спайкової кишкової непрохідності через 2 місяці-2,5 року після оперативної дезінвагінації, у 9 пацієнтів переміжну кишкову непрохідність усували консервативними заходами.

Таблиця 3. Ранні післяопераційні ускладнення у дітей з інвагінацією кишечника

\begin{tabular}{|c|c|c|}
\hline Ускладнення & абс. & $\%$ \\
\hline Абсцес черевної порожнини & 3 & 2,0 \\
\hline Інфільтрат черевної порожнини & 4 & 2,7 \\
\hline Нагноєння рани & 2 & 1,3 \\
\hline Часткова рання спайкова кишкова непрохідність & 7 & 4,7 \\
\hline Повна рання спайкова кишкова непрохідність & 4 & 2,7 \\
\hline Зовнішня кишкова нориця & 4 & 2,7 \\
\hline Евентерація & 3 & 2,0 \\
\hline Неспроможність анастомозу & 6 & 4,0 \\
\hline Абсцедуючий оментит & 1 & 0,7 \\
\hline
\end{tabular}

Примітка. У таблиці наведена абсолютна кількість ускладнень; у кількох хворих спостерігалося 2 і більше ускладнень.

Висновки. 1. Комплексний облік місцевих і загальних адаптаційних реакцій дозволяє прогнозувати перебіг і результат лікування інвагінації кишечника у дітей.

2. У прогнозуванні виникнення ускладнень і результату кишкової інвагінації у дітей можуть бути достовірно використані деякі клінічні, біохімічні, імунологічні та морфологічні показники.

3. Термін спостереження та проведення реабілітаційних заходів у дітей після оперативної дезінвагінації повинні визначатися за ступенем ризику виникнення пізніх ускладнень.

\section{Література}

1. К вопросу о рецидивирующей инвагинации кишечника у детей / Н. А. Бутакова, Ю. П. Губов, В. Н. Гогин [и др.] // Детская хирургия. - 2011. - № 2. - С. 8-11.

2. Клинико-морфологические параллели инвагинации кишечника у детей/В. Н. Грона, С. В. Веселый, Г. А. Со-

пов [и др.] // Університетська клініка. - 2007. - Т. 3, № 1. - С. 19-23.

3. Мінцер О. П. Інформаційні технології в хірургії / О. П. Мінцер, В. 3. Москаленко, С. В. Веселий. - Кн. 3. - 
в 10 книгах "Інформаційні технології в охороні здоров'я і практичній медицині".-К.: "Вища школа", 2004.-423 с. 4. Морозов Д. А. Инвагинация кишечника у детей / Д. А. Морозов, С. Ю. Городков //Российскийвестник детской хирургии, анестезиологии и реаниматологии. -2014. - Т. 4, № 1. - С. 103-110.

5. Продолжительность выделения крови из прямой кишк и - основной критерий выбора способа лечения инвагинации кишечника / Д. А. Морозов, Ю. В. Филиппов, Г. А. Староверова [и др.] // Детская хирургия. - 2010. № 6. - С. 29-32.

6. Темнова В. А. Клинико-эхографические критерии обоснования лечебной тактики у детей с инвагинацией кишечника: автореферат дисс. на соискание ученой степени канд. мед. наук / Московский научно-исследовательский институт педиатрии и детской хирургии. Москва, 2010-26 c.
7. Complex presentation of intussusception in childhood / M. J. Dawrant, J. C. Lee, C.-P. Ho, D. D. Caluwer// Pediatr. Surg. Int. - 2005. - № 21. - P. 730-732.

8. Intussusception among young children in Europe / H. Huppertz, M. Soriano-Gabarror, E. Grimprel [et al.] //The Pediatric Infectious Disease Journal. - 2006. -Vol. 25. - S. 229. A multi-country study of intussusception in children under 2 years of age in Latin America: analysis of prospective surveillance data/ S. Lorens [et al.] //BMC Gastroenterology -2013.-P. 13-95.

10. Diagnosis of Intussusception by Physician Novice Sonographers in the Emergency Department / A. Riera, A. L. Hsiao, M. L. Langhan [et al.] // Annals of Emergency Medicine. - 2012. - Vol. XX, X. - P. 1-5. 